\title{
Study of Composite Fiber Reinforcement of Cracked Thin-Walled Pressure Vessels Utilizing Multi-Scaling Technique Based on Extended Finite Element Method
}

\author{
S. H. Mirmohammad, ${ }^{a}$ M. Safarabadi, ${ }^{a}$ M. Karimpour, ${ }^{a}$ M. R. M. Aliha, ${ }^{b, 1}$ and F. Berto ${ }^{c}$ \\ ${ }^{a}$ Mechanical Engineering Department, College of Engineering of the University of Tehran, North \\ Kargar, Tehran, Iran \\ ${ }^{\mathrm{b}}$ Welding and Joining Research Center, School of Industrial Engineering, Iran University of Science \\ and Technology (IUST), Narmak, Tehran, Iran \\ ${ }^{c}$ Department of Engineering Design and Materials, Norwegian University of Science and Technology, \\ Trondheim, Norway \\ 1 mrm_aliha@iust.ac.ir
}

УДК 539.4

\section{Оценка трещиностойкости тонкостенного сосуда давления с трещиной и накладкой из армированного волокнами композита с помощью мульти- масштабирования и расширенного метода конечных элементов}

\author{
С. Х. Мирмохаммада ${ }^{a}$ М. Сафарабади ${ }^{a}$, М. Каримпур ${ }^{a}$, М. Р. М. Алиха ${ }^{6}$, Ф. Берто

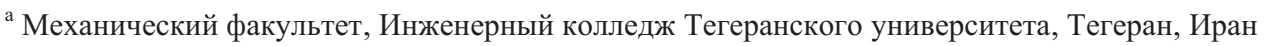 \\ б Научно-исследовательский центр сварки и соединения, Иранский университет науки и \\ технологии, Нармак, Тегеран, Иран

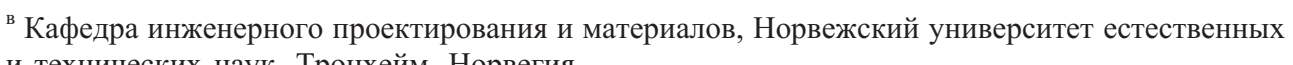 \\ и технических наук, Тронхейм, Норвегия
}

Одна из наиболее важных проблем хранения жидкостей в тонкостенных сосудах высокого давления - предотвращчение распространения трещин. При низких температурах имеет место хрупкое распространение трещии, которое является опасным. Представлена новая численная модель расчета усиления тонкостенного сосуда давления с трешчной композитной накладкой. Для моделирования роста хрупких трещин по толщине тонкостенного сосуда давления используется расширенный метод конечных элементов в сочетании с методом мультимасштабирования. Посредством расширенного метода конечных элементов рассчитывается критическая энергия, т.е. максимальная энергия деформации, которую сосуд давления может накопить до начала хрупкого распространения трещчины. Для увеличения критической энергии использовались связующие элементы и составные участки с различной последовательностью укладки, которые ранее исследовались экспериментально и аналитически, а оптимальная последовательность укладки оценивалась с помощью расширенного метода конечных элементов. Кроме того, использовалась традиционная методика оптимизации армирования композитными накладками, основанная на оптимальном соотношении увеличенной критической энергии и толщины накладки. Показано, что при постоянной толщине накладки и изменении угла укладки волокон максимальная энергоемкость увеличивается на 7...11\%. При увеличении толщины арматуры наблюдается значительный рост энергии деформации (до 40\%). Для исключения повреждения накладок при распространении трещиин использовался критерий повреждения Хашина.

Ключевые слова: тонкостенный сосуд высокого давления, расширенный метод конечных элементов, накладка из волокнистого композита, метод мультимасштабирования, механика разрушения, критерий повреждения Хашина. 
1. Background. Reinforcement of thin-walled pressure vessels has always been an important subject in the industry since it can reduce the possibility of fracture. Whether the property of the material is ductile or brittle, there is a high possibility that it shows brittle behavior under certain circumstances such as cold temperature of the fluid inside the pressure vessel. More over different shapes of the crack tend to become similar to nail-shaped crack due to the lower levels of energy.

1.1. Fracture Mechanics Based on Extended Finite Element Method (XFEM) Approach. There are several approaches to analyze crack stability and propagation. Early theories were based on local formulations, however, soon it was realized that they are unreliable due to the dependency to mesh or size. Three fundamentals approaches for discussion of defects and failures are continuum-based plasticity, damage mechanics and the crack based approach of fracture mechanics. Theory of plasticity and damage mechanics are used to analyze problems where displacement field remains continuous everywhere, and use material properties to calculate the status of the material after experiencing an amount of load. On the other hand, fracture mechanics is specifically formulated to deal with discontinuities where displacement field is discontinuous. The theory of plasticity is based on softening plasticity models and is capable of predicting initiation and propagation of the crack. The theory of damage mechanics is similar to the theory of plasticity. In the theory of damage mechanics both stiffness and strength of the material decrease if the material experience damage, however, in the theory of plasticity stiffness remains unaltered but the strength is updated due to the softening/hardening behavior. Last but not least, the theory of linear elastic fracture mechanics (LEFM) adopts the laws of thermodynamic to formulate an energy or stress intensity based criterion to analyze an existing crack. Moreover, the most important facet of LEFM is the capability to derive the singular stress field by means of the analytical solution at the crack tip. Due to the limitations of analytical methods in handling complex geometries and boundary conditions, several numerical techniques were developed for solving fracture mechanics problems. Among all of these techniques, fast developments of finite element method has a great impact on the application of LEFM which helps to implement this theory for models with complex geometries and engineering applications [1,2]. Robinovitch and Frosting conducted a research on the fiber reinforced plastic strips in order to predict interfacial delamination. They carried out an analytical stress analysis and managed to introduce energetic fracture criterion by which the basis of stable or unstable crack growth was derived. Moreover, they proposed that this criterion is more reliable to predict catastrophic failure that stress based failure criteria [3]. Colombi [4] examined the delamination failure of metallic beams reinforced by externally bonded fibres reinforced polymers (FRP), and illustrated a simplified criterion which is based on the evaluation of energy release rate (ERR) using both analytical and numerical models. Consequently, an alternative approach for the stress-based method was proposed to use ERR based criterion to evaluate the load carrying capacity of the adhesive joints. Finally, the concluded that using this fracture criterion is more convenient because it does not need burdensome evaluation of stress field especially in a discontinuity, hence, it is more applicable to industrial cases [4]. Bruno et al. [5] investigated edge debonding in beams strengthened with externally bonded composite laminated plates and evaluated strain energy release rate (ERR) by means of interface displacement jumps which is a very efficient numerical procedure. Results obtained by this procedure showed agreement with refined 2D-continuum FE investigation with high accuracy. Moreover, the analysis carried out by this approach does not suffer of non-convergence problem in the energy release rate mode components revealed by FE computations [5]. Greco et al. [6] evaluated both total and mixed mode energy release rate with an analytical solution by using stress and strain discontinuities across a crack tip for the analysis of typical edge debounding problems in concrete strengthened with externally bonded composite, and compared it with a thorough FE investigation. Their model consists 
of two mathematical layers which adopt first-order shear deformation laminate theory. Their analytical solutions for evaluating energy release rates utilizes an interface fracture analysis based on interfacial concentrated forces. This analytical approach contributes to less computation costs and avoids the complexity of detailed mesh required to capture the singularities. Therefore, the analytical solution avoids complexity of FE procedure [6]. All of the aforementioned carried out studies which adopted FEM to evaluate stress and strain in order to calculate parameters such as stress intensity factor, the energy release rate of $J$ integral to analyze cracks. Additionally, various techniques were used to produce singularity in the stress field at a crack tip, and facilitate arbitrary crack propagation which led to the introduction of the technique of Singular finite elements which was the introduction of elements with singularity in their formulation [7]. This technique was prior to the development of XFEM and suffered from some shortages. Since it has to be used in a finite element mesh, where crack face have to match element boundaries, its application had limitations unless combined with at least a local adaptive finite element scheme. However, this drawback was dealt with by introduction of XFEM which was introduced and developed by Belytschko and Black [8] they developed an algorithm based on partition of unity (PUFEM) which utilizes approximation functions which can be guessed from analytical solutions to represent the crack tip discontinuity. However, in case of severely curved cracks, minimal remeshing was needed far away from crack tip that is costly efficient. Moreover, stress intensity factors which was calculated by this method agrees with analytical solutions with high accuracey for some 2D problems [8]. Furthermore, Moës et al. [9] improved this method to make it more convenient to model long cracks. They used crack tip asymptotic functions to reproduce the discontinuity of the crack tip and Haar functions to represent the discontinuous field across the crack faces. The aforementioned method, not only is advantageous for nonlinear materials; but also utilizes mapping of the discontinuous crack tip functions for curved cracks. Last but not least, the accuracy of this method is quite independent of mesh size for a large range of sizes and overcome the need for transitions and very small mesh size near the crack tip which was proved by comparing the stress intensity factors that was calculated by this method and the analytical solutions for some 2D problems [9]. Additionally, Areias and Belytschko [10] transitioned this methods for $3 \mathrm{D}$ brittle quasi-static problems. They carried out this study utilizing tetrahedral elements and a viscosity-regularized continuum damage constitutive model in order to improve the stability of equilibrium equations. Moreover, the evolving discontinuity surface is discretize through a $C^{0}$ surface formed in order to separate each cracked elements in two. Although, there are accuracy defects in tetrahedral elements, they found that cracking results are accurate even with coarse meshes. They proposed an explanation for this adequacy which was decoupling of surface geometrical definition and dissipation mechanism in XFEM algorithm. Moreover, the novelty of this paper was taking advantage of continuum damage after the discontinuity is introduced [10]. It needs to be mentioned that formulation of the XFEM method is based on partition of unity finite element method (PUFEM) which was proposed earlier by Melenk and Babuška [11], PUFEM is a method that contributes to solution of the differential equations by using local approximations that reflects the rough behavior of the solution. Interestingly, the meshless aspect of this method is helpful for problems which have to deal with frequent remeshing. However, one of the potential drawbacks of this aspect is difficulty in integrating according to the shape functions which are not tied to the mesh. Fortunately, this issue has been dealt with in closed form integration method of previous studies [11]. Belytschko et al. [12] presented a technique to model and analyze arbitrary cracks in which both discontinuities in the function and its derivatives were considered. Additionally, they took advantage of level set method to update the position of the discontinuity. In this technique the surface of discontinuity is described by signed distance function. Hence, the discontinuity approximation involves only nodal data. However, the major drawback of this method is 
the quadrature of the weak form such that utilizing quadrature elements requires certain modifications [12]. A variational (weak) form of any equation involves multiplying an arbitrary vector with a free index and integrating the result over the domain which is analogous to integrating work over a closed domain which equals to zero. In solving partial differentials equations this technique is used to reduce derivatives which contributes to reduce computational costs [13]. Areias and Belytschko [14] proposed a new formulation for the analysis of arbitrary crack propagation in shells. Moreover, they used a modified formulation for the 4-noded cracked shell elements to avoid locking. They compared the results of intensity factors from this method to previous methods which showed good agreement [14]. Budarapua et al. [15] proposed a multi-scale numerical method for quasi static crack growth. Phantom node method is used to model the crack in the continuum region and a molecular statics model is used near the crack tip [15]. Furthermore, several research have been conducted recently which investigated the applications of this method. Sharma et al investigated the stress intensity factor of a semi-elliptical part through thickness axial/circumferential crack in a pipe bend under internal pressure loading using XFEM method. They concluded that axial crack is more severe than the circumferential crack under same loading and boundary conditions. At the end, they compared the results of SIF evaluated form XFEM to the results from regular FEM and claimed that not only it showed a good agreement; but also; using XFEM is more convenient [16]. Zhang et al. [17] investigated ductile fracture of API X65 buried pipeline including crack initiation and propagation using XFEM. At the very first step, they evaluated GIC and Maxps of the materials using experimental data of three point bending test and numerical analysis. These material properties have the most important effect on the fracture behavior of a material such that the value of the Maxps is the critical maximum principal stress at which a crack initiates. Also $G_{I c}$ is the critical value that indicates the resistance of the material against the crack propagation. More $G_{\text {Ic }}$ value; gentler decrease in the load bearing capacity. After evaluating the closest values to the experimental data, they used them to investigate the fracture of the same pipe-line which is buried in the soil which is subjected to land-sliding. They used linear elastic Drucker-Prague model as the mechanical properties of the soil. Last but no least they concluded that using XFEM method is more conservative than using nonlinear stabilization algorithm in case of investigating load bearing capacity since it takes the damage effects of material into the consideration and provides a fundamental support for the integrity assessment and safety evaluation of buried pipes [17].

1.2. Fiber Composite Reinforcement. There has been plenty of studies both analytically and experimentally to investigate the effects of the angles of fibers and stacking sequence in a composite on the reinforcement of the pressure vessels. Also since crack propagation results in a shear stress load on the cohesive element and the composite reinforcement, considering damage analysis of the both cohesive element and composite reinforcement is of importance. Hashin proposed four distinct failure modes-tensile and compressive fiber and matrix modes for three-dimensional unidirectional fiber composites. The novelty of this work is to predict distinct failure modes which is helpful for progressive damage analysis which contributes to set up a FE procedure and predict the exact situation of the fiber and matrix [18]. Al-Khalil et al. [19] investigated several filament wound glass fiber reinforced epoxy cylinders with winding angles of $\pm 35, \pm 55$, and \pm 75 and stated that the mode of the failure depends on the winding angle. Liu et al. [20] performed an analysis based on continuum damage mechanics, the progressive failure analysis using explicit finite element method to predict failure properties and burst strength of aluminum-carbon fiber/epoxy composite cylindrical laminate structures. The used viscous damping effect for convergence of the problem to properly deal with strain softening phenomenon. Also, they concluded that in case of progressive damage explicit method shows a better convergence in comparison with the implicit method [20]. 


\section{Numerical Modeling.}

2.1. Crack Modeling Based on XFEM. Abaqus software is used to develop a FE model. One of the most recent and novel algorithms to analyze discontinuity is using XFEM procedure. Using this method, both modeling of crack initiation which uses LEFM and propagation which uses traction separation cohesive behavior is possible. Either of these methods use an energy based law according to the thermodynamics principals which says a system always tries to reach the lowest level of energy. Modeling the problem starts with investigating a thin-walled pressure vessel modeled with shell elements under static internal pressure. The pressure vessel diameter is $1 \mathrm{~m}$ and the length of the cylindrical part is $4 \mathrm{~m}$. Since the XFEM crack can only be represented in solid elements, using multiscaling technique which can be implemented in the model as submodeling technique in abaqus is needed. Hence, shell to solid submodeling is used in order to drive the nodes of the solid elements using displacement of the shell elements.

Validation of this method and its implementation was done under the static pressure by the analytical solution. As it is known form the analytical solution the hoop stress is calculated by $P D_{m} / 2 t$, in which the $P, t$, and $D_{m}$ are internal pressure, thickness, and mean diameter, respectively. As it is shown in Fig. 1 the hoop stress under $10 \mathrm{MPa}$ internal pressure for a pressure vessel with mean diameter of $1 \mathrm{~m}$ and thickness of $10 \mathrm{~mm}$ is $500 \mathrm{MPa}$.

In order to model the XFEM crack, damage for traction-seperation laws is used as the appropriate theory and parameters of steel for this theory is as Table 1, where $E$ and $v$ are elastic modulus and Poisson's ratio, respectively. Also MPS and $G$ are the maximum principal stress in which the crack initiates and the critical energy release rate, respectively.

$\mathrm{T}$ a $\mathrm{b} 1 \mathrm{e} 1$

Material Properties of Steel [21]

\begin{tabular}{|c|c|c|c|}
\hline$E, \mathrm{GPa}$ & $M P S, \mathrm{MPa}$ & $v$ & $G, \mathrm{~J} / \mathrm{m}^{2}$ \\
\hline 210 & 440 & 0.3 & $107,142.8571$ \\
\hline
\end{tabular}

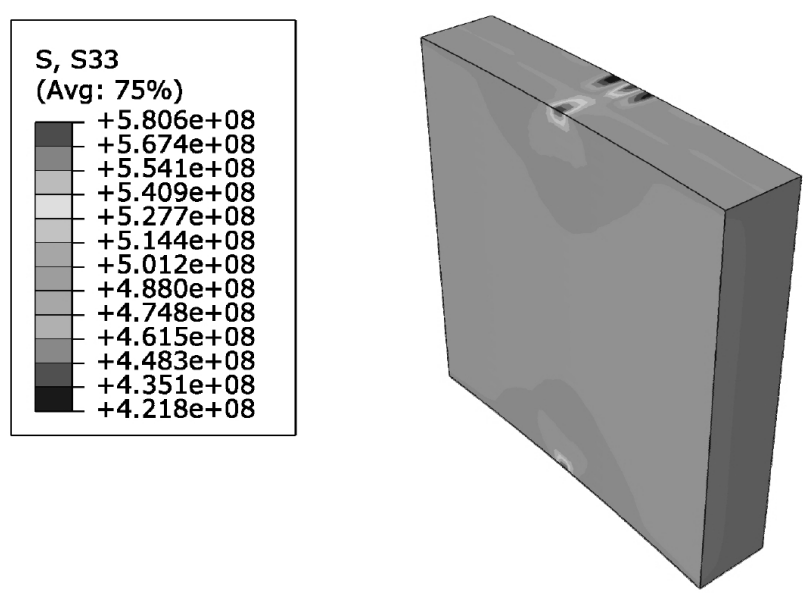

Fig. 1. Hoop stress contour in submodel.

Now it is needed to specify the shape of the crack which is a nailed-shaped crack in the thickness of the submodel.

The width of the crack is $1 \mathrm{~mm}$ and only the curved part of the crack geometry has been inserted to the submodel. It needs to be mentioned that a part of the crack must be outside of the thickness so the software can comprehend it as a crack also a mesh and a 
material property should not be assigned to the crack. In order to assign the XFEM property to the model step-special-crack-create-XFEM is used. Also a hard contact to the surfaces of the crack is assigned to avoid the surfaces of the crack to go inside each other [22].

For improving the convergence of the solution a viscosity for the material in the material property which can be $1-\mathrm{E} 5 \mathrm{~Pa} \cdot \mathrm{s}$ is assumed. Moreover, an automatic stabilization can be used in the step module to improve the unstable response. As the crack starts to grow, there would be an abrupt fall in the strain energy of the submodel after absorbing an amount of strain energy which represents the toughness of the material.

2.2. Reinforcement Patch Modeling. In this study, it is tried to increase this critical energy by cohesive elements and composite reinforcement. For this mean, a shell to which a composite lay-up is assigned is modeled. The composite lay-up has the same length and width as the submodel pressure vessel. In this paper, the carbon-epoxy (T300/5208) composite has been used. The mechanical properties of this composite is as Table 2 that has been extracted from [23].

Here, $E_{1}, E_{2}$, and $v_{12}$ are the longitudinal and transversal moduli and Poisson's ratio, respectively, $G_{12}, G_{13}$, and $G_{23}$ are regarding shear moduli, $X^{T}$ and $X^{C}$ are the longitudinal tensile and compressive strength, respectively, $Y^{T}$ and $Y^{C}$ are transverse tensile and compressive strength, respectively, and $S^{L}$ and $S^{T}$ are shear longitudinal and transverse strength, respectively.

$\mathrm{T}$ a b 1 e 2

Elastic and Strength Properties of Carbon-Epoxy [23]

\begin{tabular}{|c|c|c|c|c|c|c|c|c|c|c|c|}
\hline $\begin{array}{c}E_{1}, \\
\mathrm{GPa}\end{array}$ & $\begin{array}{c}E_{2}, \\
\mathrm{GPa}\end{array}$ & $v_{12}$ & $\begin{array}{c}G_{12}, \\
\mathrm{GPa}\end{array}$ & $\begin{array}{c}G_{13}, \\
\mathrm{GPa}\end{array}$ & $\begin{array}{c}G_{23}, \\
\mathrm{GPa}\end{array}$ & $\begin{array}{c}X^{T}, \\
\mathrm{MPa}\end{array}$ & $\begin{array}{c}X^{C}, \\
\mathrm{MPa}\end{array}$ & $\begin{array}{c}Y^{T}, \\
\mathrm{MPa}\end{array}$ & $\begin{array}{c}Y^{C}, \\
\mathrm{MPa}\end{array}$ & $\begin{array}{c}S^{L}, \\
\mathrm{MPa}\end{array}$ & $\begin{array}{c}S^{T}, \\
\mathrm{MPa}\end{array}$ \\
\hline 181 & 10.3 & 0.28 & 7.17 & 6.0 & 6.0 & 1500 & 1500 & 40 & 246 & 68 & 68 \\
\hline
\end{tabular}

2.3. Cohesive Element Modeling. In order to model a cohesive element a solid element with the thickness of $0.1 \mathrm{~mm}$ is modeled. Cohesive element has the same length and width as the submodel pressure vessel. Also the cohesive element which has been used to attach the composite lay-up to the submodel is Araldite 420 that has uncoupled mechanical properties as Tables 3 and 4 . In which $E_{n n}, E_{s s}$, and $E_{t t}$ are the main diagonal entries of the stiffness matrix. Also, in order to investigate the damage of the cohesive element under shear stress resulted from crack propagation, maximum damage properties for the cohesive element have been used. The material properties has been extracted from [24]. It is worth mentioning that that properties has been extracted form an upcomng paper by Shahriyarifard et al. [24].

$\mathrm{T}$ a b 1 e 3

Elastic and Strength Properties of Cohesive Element Araldite 420 [24]

\begin{tabular}{|c|c|c|c|c|c|}
\hline $\begin{array}{c}E_{n n}, \\
\mathrm{GPa}\end{array}$ & $\begin{array}{c}E_{s s}, \\
\mathrm{MPa}\end{array}$ & $\begin{array}{c}E_{t t}, \\
\mathrm{MPa}\end{array}$ & $\begin{array}{c}\text { Nominal stress } \\
\text { normal-only mode } \\
(\mathrm{MPa})\end{array}$ & $\begin{array}{c}\text { Nominal stress } \\
\text { first direction } \\
(\mathrm{MPa})\end{array}$ & $\begin{array}{c}\text { Nominal stress } \\
\text { second direction } \\
(\mathrm{MPa})\end{array}$ \\
\hline 1.85 & 7.17 & 7.17 & 30.0 & 14.5 & 14.5 \\
\hline
\end{tabular}

2.4. Assembly of the Model. To assemble the model to be a good representative of the reality, the cohesive element and the submodel have been merged. Moreover, the composite lay-up has been tied to the cohesive element which is a decent assumption during the analysis. 
$\mathrm{T}$ a b 1 e 4

Damage Properties of Cohesive Element Araldite 420 [24]

\begin{tabular}{|c|c|c||}
\hline $\begin{array}{c}\text { Shear mode fracture } \\
\text { first direction }(\mathrm{N} / \mathrm{m})\end{array}$ & $\begin{array}{c}\text { Shear mode fracture energy } \\
\text { second direction }(\mathrm{N} / \mathrm{m})\end{array}$ & $\begin{array}{c}\text { Normal mode fracture energy } \\
(\mathrm{N} / \mathrm{m})\end{array}$ \\
\hline 4700 & 4700 & 4000 \\
\hline
\end{tabular}

2.5. Mesh Study. Also mesh study has been conducted on both submodel and composite lay-up to reach a mesh size that results a solution which is independent of the mesh size. To reach this objective different mesh sizes for submodel were used and for each mesh size, the critical energy as the objective of the mesh study process was calculated by numerical methods.

As it was mentioned earlier in the literature review, XFEM algorithm is independent of the mesh size after some practice so the mesh size with 85833 DOFs is considered. Moreover, the shape of the evolved crack differs according to the integration points in the elements and since full integration elements results more accurate solution, full integration linear Hex elements which have 8 integration points are considered. The shape of the crack with both reduced integration points and full integration points is shown in Fig. 2.

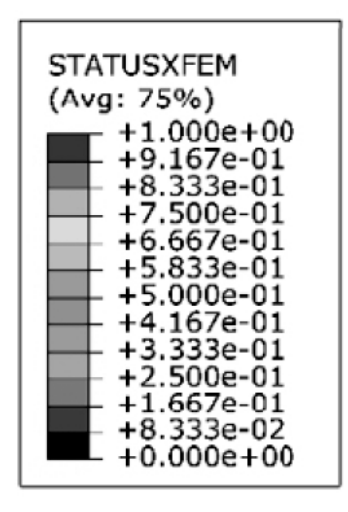

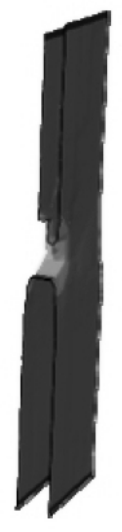

a

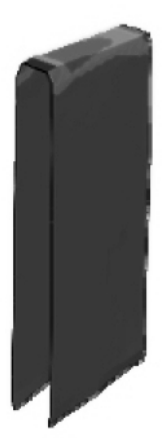

b

Fig. 2. Shape of the evolved crack with (a) reduced integration points elements and (b) full integration points elements.

Additionally, a mesh study has been conducted on the composite lay-up. Hence, linear quad elements with 13,668 DOFs were used.

Last but not least, the global model of pressure vessel which was modeled by shell elements, must be partitioned to be possible to have a composite lay-up section at the exact same place of the submodel.

3. Results and Discussion. In this paper, crack propagation in the thickness of a pressure vessel was studied utilizing the combination of XFEM approach in fracture mechanics and multi-scaling technique. Several stacking sequences and stacking angles were used to reinforce the thin-walled pressure vessel. The nailed-shape crack has the width of $1 \mathrm{~mm}$ and the depth of $0.5 \mathrm{~mm}$. The submodel, cohesive element and the composite patch all have the length and width of $50 \mathrm{~mm}$ which would be big enough to avoid edge effects of submodel. In the parametric studies, several angle sequences were examined which were extracted from previous studies [19]. Also, the thickness of the cohesive element has been set as $0.1 \mathrm{~mm}$ both in the geometry and the section property which is based on [22]. 
Before the beginning of the case studies, the maximum strain energy that the submodel of the pressure vessel can absorb before the crack propagates entirely in the thickness of the solid submodel of the pressure vessel was calculated. The diagram of the strain energy in Fig. 3 shows that after absorbing a specific amount of strain energy the material losses its load bearing capacity and the strain energy abruptly falls. In this paper, the goal is to increase this critical energy using cohesive elements and composite patches with different reinforcement angles and thickness.

It has been observed in Fig. 4 that by reinforcing the submodel the maximum principal stress at the crack tip decreases which contributes to prevent the unstable crack propagating in a brittle material.

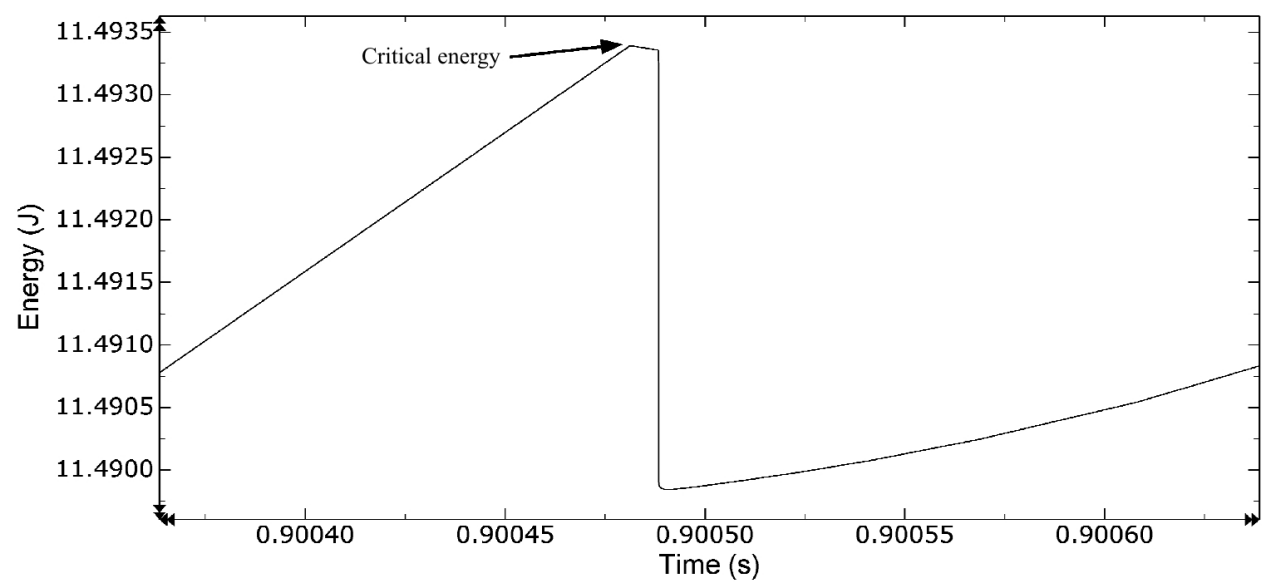

Fig. 3. Evolution of the strain energy as the crack propagates.
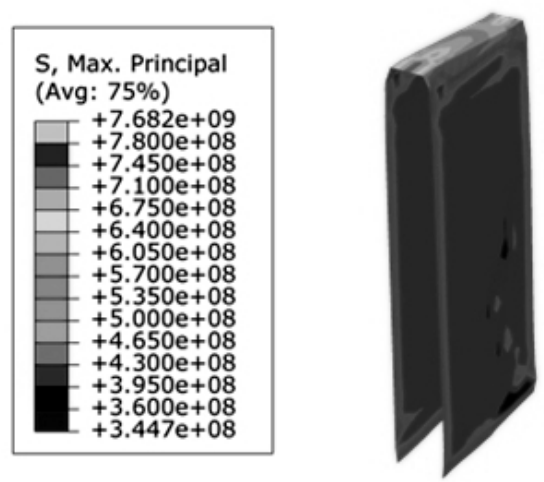

a

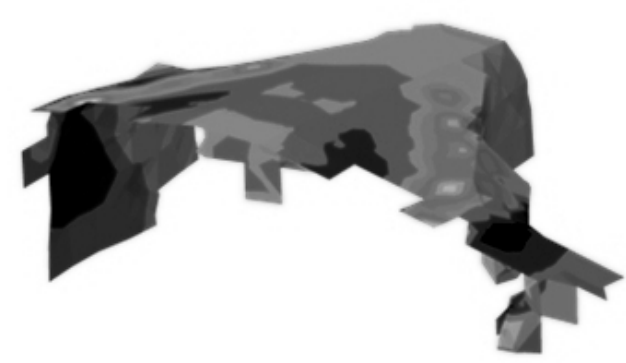

b

Fig. 4. Maximum principal stress at the crack tip: non-reinforced (a) and reinforced (b) submodels.

3.1. Effects of Reinforcement Thickness. In this case study, a stacking angle which would be $0 / 45 /-45 / 90$ is selected to evaluate the optimum ratio of the increase in reinforcement to the thickness of the reinforcement which can increase by repeating the angle pattern. Since each lamina has the thickness of $0.2 \mathrm{~mm}$, then each pattern would have the thickness of $0.8 \mathrm{~mm}$. Figure 5 shows the results.

As the results show, increasing the thickness more than $2.4 \mathrm{~mm}$ is a waste of material because it does not result in adequate increase in the reinforcement. Moreover, as the 


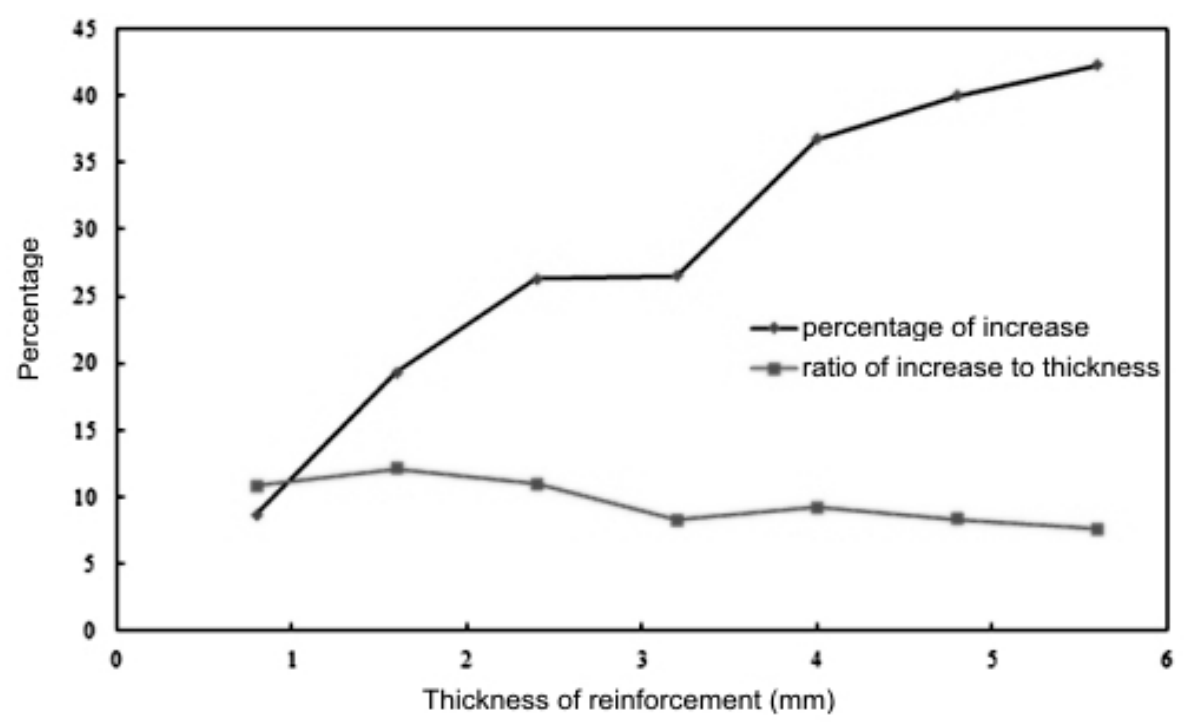

Fig. 5. Effect of increase in the thickness on the reinforcement.
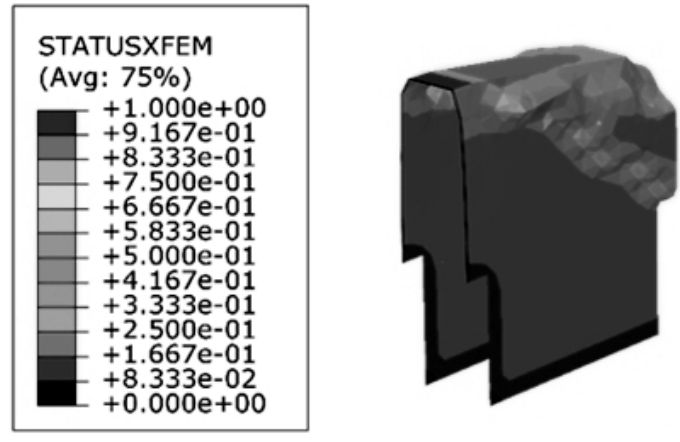

a

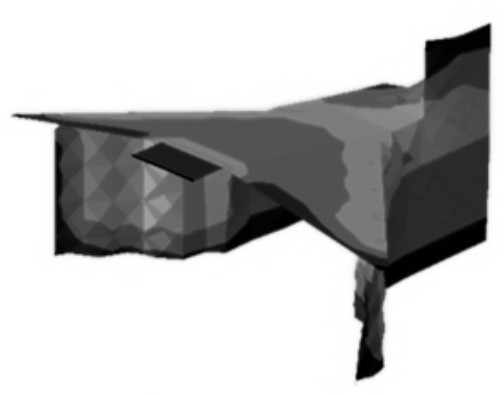

b

Fig. 6. Evolved crack shape with (a) 4 layers of reinforcement and (b) 20 layers of reinforcement.

thickness of the reinforcement is increased the shape of the evolved crack differs and would get wider as it is shown in Fig. 6.

3.2. Effects of Stacking Angle. In this case study, the effects of different stacking angles which are popular angles or are extracted from [19] on the degradation of the cohesive element have been investigated. It is crystal clear that each angle pattern that provides more reinforcement, can distribute the load more effectively in the cohesive element, hence the cohesive element would experience less degradation. Degradation of the cohesive element can be calculated using SDEG output and the results for two stacking angle is shown in Fig. 7. As it is observed in the results, $75 /-75 / 75 /-75$ and $55 /-55 / 55 /-55$ stacking angles result less cohesive element degradation than the other stacking angles.

3.3. Traditional Optimization. In this case study, it has been tried to reach the optimum reinforcement thickness using traditional optimization method for fiber- reinforcing problems. In each run, the thickness of the reinforcement has been increased and the critical strain energy has been extracted from the FEM software. Figure 8 shows the percentage of increase in the critical energy as the thickness of reinforcement is increased. Also, Fig. 9 shows the ratio of increase in energy resulted from each step to the thickness of each step. 


\begin{tabular}{|l|}
\hline \multicolumn{1}{|l|}{ SDEG } \\
(Avg: $75 \%$ ) \\
$+7.936 \mathrm{e}-01$ \\
$+7.275 \mathrm{e}-01$ \\
$++6.613 \mathrm{e}-01$ \\
$+5.952 \mathrm{e} 01$ \\
$+5.291 \mathrm{e}-01$ \\
$+4.629 \mathrm{e}-01$ \\
$+3.968 \mathrm{e}-01$ \\
$+3.307 \mathrm{e}-01$ \\
$+2.645 \mathrm{e}-01$ \\
$+1.984 \mathrm{e}-01$ \\
$+1.323 \mathrm{e}-01$ \\
$+6.613 \mathrm{e}-02$ \\
$+0.000 \mathrm{e}+00$ \\
\hline
\end{tabular}

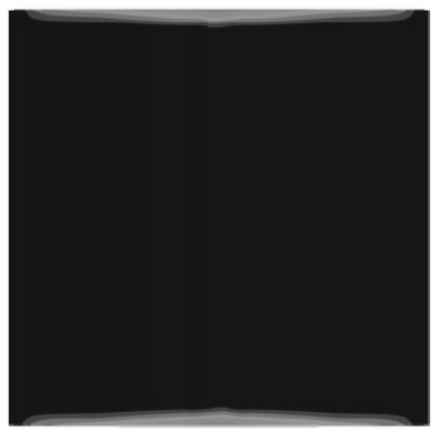

a

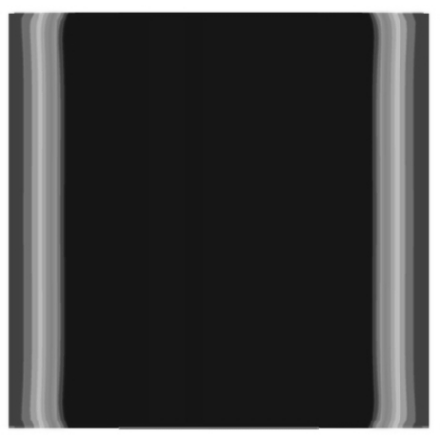

b

Fig. 7. SDEG output of the cohesive element resulted from (a) $75 /-75 / 75 /-75$ and (b) $0 / 0 / 90 / 90$ stacking angles.

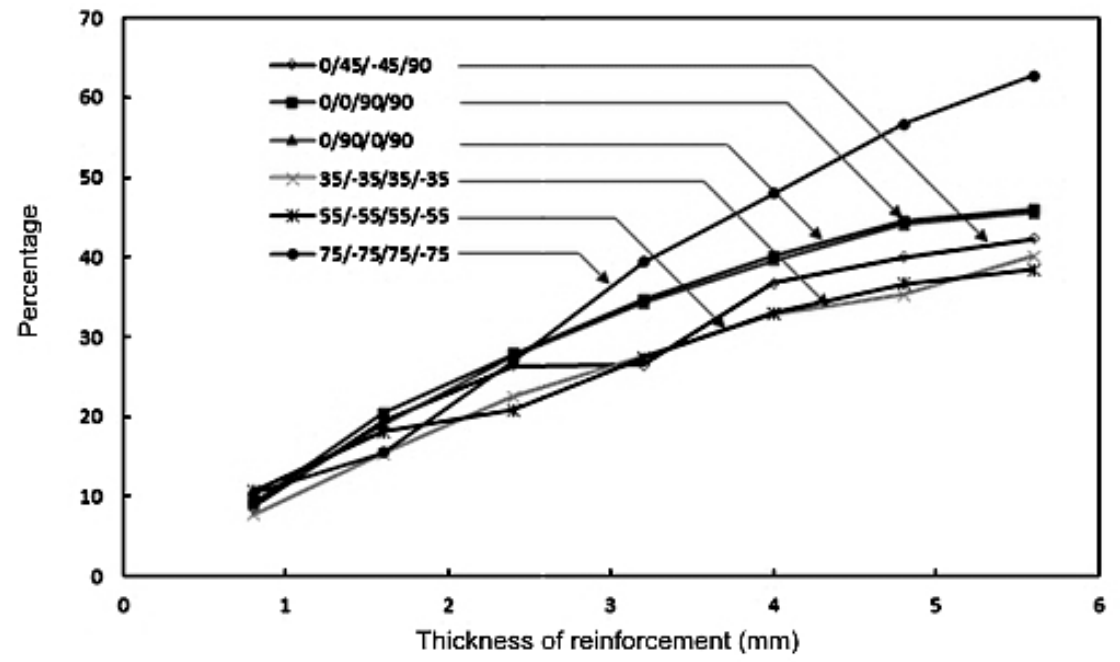

Fig. 8. Effect of the thickness of the reinforcement on the increase of the critical strain energy.

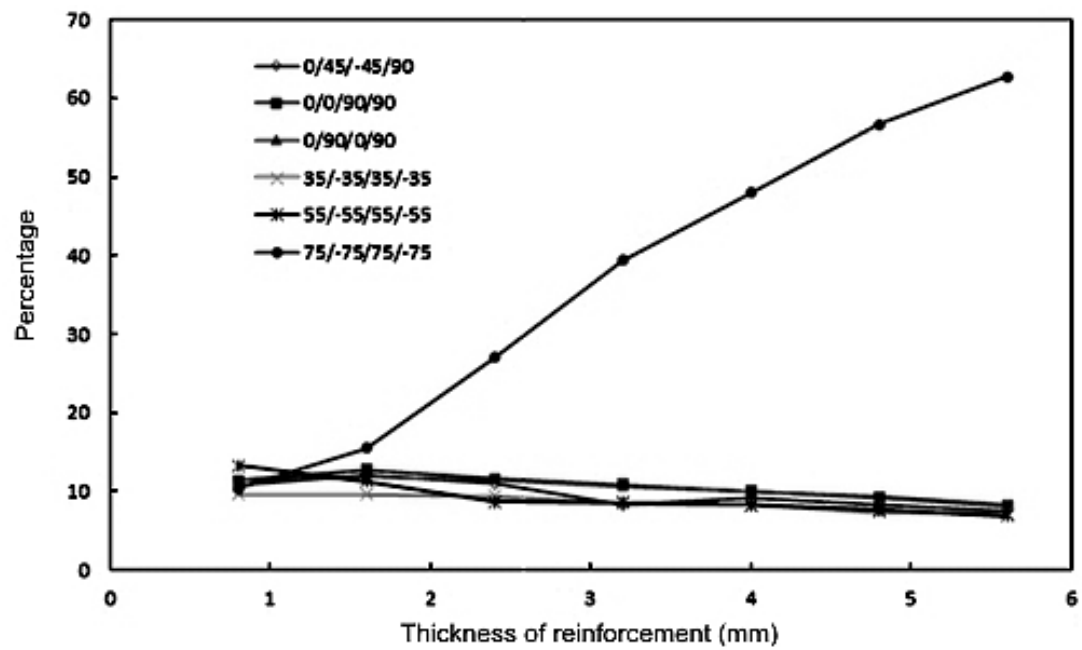

Fig. 9. Effect of thickness of the reinforcement on the ratio of critical energy increase to the reinforcement thickness. 


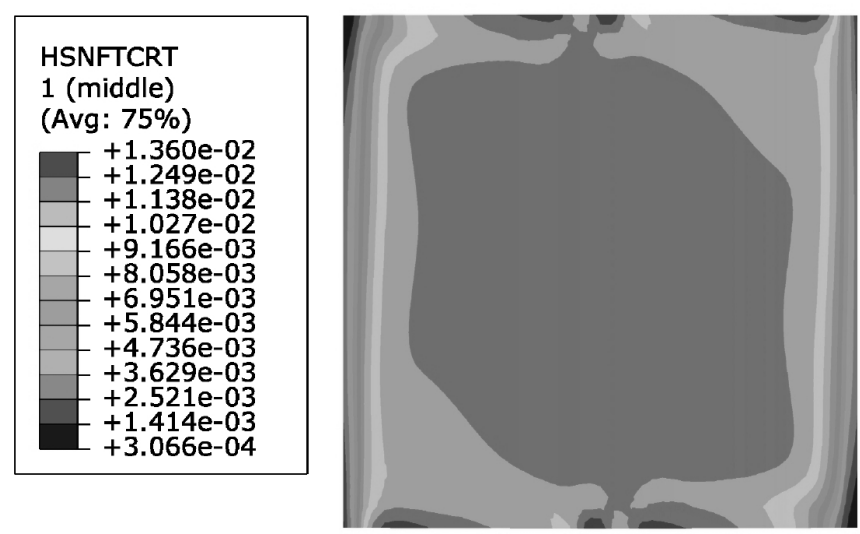

Fig. 10. Hashin damage criterion for fibers in tension.
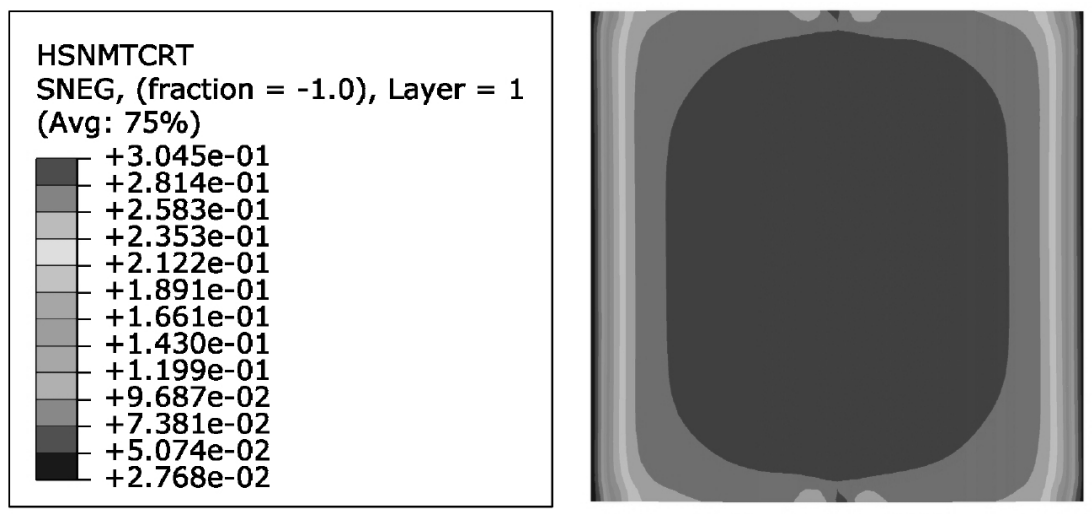

Fig. 11. Hashin damage criterion for matrix in tension.

According to the diagrams, it can be concluded that:

Reinforcing with $0 / 45 /-45 / 90$ : In case that the reinforcement is more important, $26.35 \%$ reinforcement which can be achieved by $2.4 \mathrm{~mm}$ reinforcement thickness is the best. On the other hand, in case that mass of the system is more important, $19.33 \%$ reinforcement which can be achieved by $1.6 \mathrm{~mm}$ reinforcement thickness is the best.

Reinforcing with 0/0/90/90: The best state of reinforcement is $20.4 \%$ which can be achieved by $1.6 \mathrm{~mm}$ reinforcement thickness.

Reinforcing with 0/90/0/90: In case that the reinforcement is more important, 27.51\% reinforcement which can be achieved by $2.4 \mathrm{~mm}$ reinforcement thickness is the best. On the other hand, in case that mass of the system is more important, $18.9 \%$ reinforcement which can be achieved by $1.6 \mathrm{~mm}$ reinforcement thickness is the best.

Reinforcing with $35 /-35 / 35 /-35$ : In case that the reinforcement is more important, $22.5 \%$ reinforcement which can be achieved by $2.4 \mathrm{~mm}$ reinforcement thickness is the best. On the other hand, in case that mass of the system is more important, $15.4 \%$ reinforcement which can be achieved by $1.6 \mathrm{~mm}$ reinforcement thickness is the best.

Reinforcing with $55 /-55 / 55 /-55$ : In case that the reinforcement is more important, $18.13 \%$ reinforcement which can be achieved by $1.6 \mathrm{~mm}$ reinforcement thickness is the best. On the other hand, in case that mass of the system is more important, $10.6 \%$ reinforcement which can be achieved by $0.8 \mathrm{~mm}$ reinforcement thickness is the best.

Reinforcing with $75 /-75 / 75 /-75$ : in case that the reinforcement is more important, $39.4 \%$ reinforcement which can be achieved by $3.2 \mathrm{~mm}$ reinforcement thickness is the best. 
On the other hand, in case that mass of the system is more important, 10.29\% reinforcement which can be achieved by $0.8 \mathrm{~mm}$ reinforcement thickness is the best.

Last but not the least, using relative criterions for damage in fibers and matrix, none of them experience damage based on the Hashin damage criteria which is shown in Figs. 10 and 11 .

Conclusions. In this paper, reinforcement of thin-walled pressure vessels with composite patches utilizing Multi-scaling technique was studied. Different angle patterns that were introduced by means of experiments in previous studies were used and were investigated using XFEM code. Various decisions can be made according to the results of current FEM code.

To wrap it up, in case the reinforcement is more important, reinforcing the pressure vessel with $75 /-75 / 75 /-75$ angles with thickness of $3.2 \mathrm{~mm}$ is the best among all of the other reinforcements. Moreover, in case where the mass of the system is more important either $0 / 45 /-45 / 90$ scheme with $1.6 \mathrm{~mm}$ thickness or $55 /-55 / 55 /-55$ scheme with thickness of $0.8 \mathrm{~mm}$ can be used.

\section{Резюме}

Однією з найбільш важливих проблем зберігання рідини в тонкостінних посудинах високого тиску є запобігання розповсюдженню тріщин. При низьких температурах має місце крихке розповсюдження тріщин, що є небезпечним. Представлено нову числову модель розрахунку підсилення тонкостінної посудини тиску з тріщиною композитною накладкою. Для моделювання росту крихких тріщин по товщині тонкостінної посудини тиску використовується розширений метод скінченних елементів у поєднанні з методом мультимасштабування. За допомогою розширеного методу скінченних елементів розраховується критична енергія, тобто максимальна енергія деформації, яку посудина тиску може накопичити до початку крихкого розповсюдження тріщини. Для збільшення критичної енергії використовувались зв'язувальні ділянки з різною послідовністю укладання, які раніше досліджувались експериментально й аналітично, а оптимальна послідовність укладання оцінювалась розширеним методом скінченних елементів. Окрім того, використовувалась традиційна методика оптимізації армування композитними накладками, що базується на оптимальному співвідношенні збільшеної критичної енергії і товщини накладки. Показано, що при постійній товщині накладки і зміні кута укладання волокон максимальна енергоємність збільшується на $7 \ldots 10 \%$. При збільшенні товщини арматури значно зростає енергія деформації (до 40\%). Для виключення пошкодження накладок при розповсюдженні тріщини використовувався критерій пошкодження Хашина.

1. T. L. Anderson, Fracture Mechanics: Fundamentals and Applications, CRC Press (2005).

2. S. Mohammadi, Extended Finite Element Method: For Fracture Analysis of Structures, John Wiley \& Sons (2008).

3. O. Rabinovitch and Y. Frostig, "Delamination failure of RC beams strengthened with FRP strips - a closed-form high-order and fracture mechanics approach," J. Eng. Mech., 127, No. 8, 852-861 (2001).

4. P. Colombi, "Reinforcement delamination of metallic beams strengthened by FRP strips: fracture mechanics based approach," Eng. Fract. Mech., 73, No. 14, 19801995 (2006).

5. D. Bruno, R. Carpino, and F. Greco, "Modelling of mixed mode debonding in externally FRP reinforced beams," Compos. Sci. Technol., 67, Nos. 7-8, 1459-1474 (2007). 
6. F. Greco, P. Lonetti, and P. N. Blasi, "An analytical investigation of debonding problems in beams strengthened using composite plates," Eng. Fract. Mech., 74, No. 3, 346-372 (2007).

7. A. J. Fawkes, D. R. J. Owen, and A. R. Luxmoore, "An assessment of crack tip singularity models for use with isoparametric elements," Eng. Fract. Mech., 11, No. 1, 143-159 (1979).

8. T. Belytschko and T. Black, "Elastic crack growth in finite elements with minimal remeshing," Int. J. Num. Meth. Eng., 45, No. 5, 601-620 (1999).

9. N. Moës, J. Dolbow, and T. Belytschko, "A finite element method for crack growth without remeshing," Int. J. Num. Meth. Eng., 46, No. 1, 131-150 (1999).

10. P. M. A. Areias and T. Belytschko, "Analysis of three-dimensional crack initiation and propagation using the extended finite element method," Int. J. Num. Meth. Eng., 63, No. 5, 760-788 (2005).

11. J. M. Melenk and I. Babuška, "The partition of unity finite element method: basic theory and applications," Comput. Meth. Appl. M., 139, Nos. 1-4, 289-314 (1996).

12. T. Belytschko, N. Moës, S. Usui, and C. Parimi, "Arbitrary discontinuities in finite elements," Int. J. Num. Meth. Eng., 50, No. 4, 993-1013 (2001).

13. O. C. Zienkiewicz and R. L. Taylor, The Finite Element Method for Solid and Structural Mechanics, Butterworth-Heinemann (2005).

14. P. M. A. Areias and T. Belytschko, "Non-linear analysis of shells with arbitrary evolving cracks using XFEM," Int. J. Num. Meth. Eng., 62, No. 3, 384-415 (2005).

15. P. R. Budarapu, R. Gracie, S. P. A. Bordas, and T. Rabczuk "An adaptive multiscale method for quasi-static crack growth," Comput. Mech., 53, No. 6, 1129-1148 (2014).

16. K. Sharma, I. V. Singh, B. K. Mishra, and V. Bhasin, "Numerical modeling of part-through cracks in pipe and pipe bend using XFEM," Proc. Mater. Sci., 6, 72-79 (2014).

17. B. Zhang, C. Ye, B. Liang, et al., "Ductile failure analysis and crack behavior of X65 buried pipes using extended finite element method," Eng. Fail. Anal., 45, 26-40 (2014).

18. Z. Hashin, "Failure criteria for unidirectional fiber composites," J. Appl. Mech., 47, No. 2, 329-334 (1980).

19. M. F. S. Al-Khalil, P. D. Soden, R. Kitching, and M. J. Hinton, "The effects of radial stresses on the strength of thin-walled filament wound GRP composite pressure cylinders," Int. J. Mech. Sci., 38, No. 1, 97-120 (1995).

20. P. F. Liu, L. J. Xing, and J. Y. Zheng, "Failure analysis of carbon fiber/epoxy composite cylindrical laminates using explicit finite element method," Compos. Part B-Eng., 56, 54-61 (2014).

21. D. Roylance, Mechanical Properties of Materials, Massachusetts Institute of Technology (2008), pp. 51-78.

22. Abaqus User's Guide, Abaqus 6.13 Documentation (2013).

23. H. T. Hahn and S. W. Tsai, Introduction to Composite Materials, CRC Press (1980).

24. M. M. Shahryarifard, M. Golzar, and M. Safarabadi, "Investigation of the geometrical parameters effect on laminated GFRP/steel circular tube joints," in: Proc. of the Int. Conf. on Composites Pipes, Vessels \& Tanks (Tehran, Iran, 2015). 